\title{
Chilling and Heat Requirements of 20 Iranian Pomegranate Cultivars and Their Correlations with Geographical and Climatic Parameters, as well as Tree and Fruit Characteristics
}

\author{
Ali Akbar Ghasemi Soloklui \\ Department of Horticultural Science, School of Agriculture, Shiraz \\ University, Shiraz, Iran
}

\begin{abstract}
Ali Gharaghani ${ }^{1}$
Department of Horticultural Science, School of Agriculture, Shiraz University, Shiraz, Iran; and Drought Research Center, School of Agriculture, Shiraz University, Shiraz, Iran
\end{abstract}

Nnadozie Oraguzie

Department of Horticulture, Irrigated Agriculture, Research and Extension Center, Washington State University, 24106 North Bunn Road, Prosser, WA 99350

\section{Saeid Eshghi}

Department of Horticultural Science, School of Agriculture, Shiraz University, Shiraz, Iran

\section{Mohammadreza Vazifeshenas \\ Agriculture and Natural Resources Research Center, Yazd, Iran}

Additional index words. low chill cultivars, altitude, wind speed, seed hardness, stomatal density

\begin{abstract}
Chilling and heat requirements can affect agroclimatic distribution, growing season, and the marketing period of pomegranate (Punica granatum $\mathbf{L}$.) cultivars in commercial production. This study was carried out to determine the chilling and heat requirements of 20 Iranian pomegranate cultivars/accessions, and to also examine the correlation of these features with tree and fruit characteristics, as well as geographic and climatic parameters of the original environment the plant materials came from. Oneyear-old stem cuttings from mature trees were used for measurements of chilling and heat requirements. The results showed a range of variation in chilling requirement among cultivars from 233 to 633 hours and heat requirement from 4096 to 7928 growing degree hour (GDH). Based on chill hours accumulated, cultivars including Bihaste Ravar, Bihaste Sangan Khash, and Anar Siah were categorized as very low chill (233-266 hours), whereas cultivars Poost Nazok Torosh Abarkuh, Malas Yazdi, Jangali Poost Ghermez Roodbar, Rabab Poost Ghermez Neyriz, and Makhmal Malas Shahreza were grouped as low chill (600-633 hours). Variation in seed hardness from 15 to $78 \mathrm{~N}$ was also recorded. Chilling requirement showed a moderate correlation with stomatal density, seed hardness, and wind speed $(r=0.42,0.44$, and -0.39 , respectively), whereas stomatal density showed correlations of $r=-0.34$ and -0.57 with altitude and wind speed, respectively. We suggest taking chilling and heat requirements into account when selecting individual's cultivars and/or accessions suitable for cultivation in different agroclimatic regions.
\end{abstract}

Pomegranate is highly adaptive to a wide range of climatic and soil conditions and is widely grown in both tropical and subtropical regions of Iran, India, Turkey, Afghanistan, Spain, Egypt, and other parts of North Africa,

Received for publication 30 Nov. 2016. Accepted for publication $30 \mathrm{Jan} .2017$.

${ }^{1}$ Corresponding author. E-mail: agharghani@ shirazu.ac.ir. improvement through selection for low, medium, and high chilling and heat requirements, to facilitate extension of the climatic distribution of pomegranate production in temperate, subtropical, and tropical regions.

The distribution of plant species and the structure of plant communities depends on dispersal between habitat patches and stochastic extinctions, as well as environmental sorting (i.e., deterministic extinctions) (Dupré and Ehrlén, 2002). It is generally accepted that the effect of the local environment on plant growth accounts in part for much of the variation in adult form within a species. In addition, precisely regulated responses to the environment not only allow a plant to survive from day to day, but also determine when a flowering plant will produce flowers (Raven and Johnson, 1986). Most woody deciduous fruit trees in the subtropical environments, including pomegranate, require specific chilling units to break endodormancy before active vegetative growth in the spring. Therefore, planting cultivars with different chilling requirements, in distinct climatic zones, can affect the growing and marketing period (Gratacós and Cortés, 2007). In temperate perennial crops, flower bud initiation and development in late summer and autumn is followed by winter dormancy, which involves an extended sequence of morphological, physiological, and metabolic changes (Atkinson et al., 2013). Flower bud initiation and development in pomegranate is not clearly understood, but Porter and Wetzstein (2014) showed that flower initiation in pomegranate is associated with early spring growth. In the other hand, Babu (2010) believe that flower initiation in this crop takes place at varied times under tropical condition. In regions with subtropical conditions, inadequate amount of chill units causes problems such as erratic and uneven budbreak, and consequently, a decrease in the quantity and quality of fruit produced (Allan and Burnett, 1995; Lang, 1987). The study of dormancy has considerable economic impact on the control and production of herbaceous and woody plants. Moreover, the bud dormancy of deciduous fruit trees such as apple, pear, cherry, peach, walnut, almond, pomegranate, etc., in temperate climates allow them to survive harsh environmental conditions during winter (Faust et al., 1991). Chilling requirement is one of the main factors controlling adaption of plants to the appropriate climate (Aslamarz et al., 2009). In addition, the chilling requirement for budbreak in fruit trees has to be fully satisfied to obtain the desired shoot growth and maximize fruit production (Samish and Lavee, 1982; Weldon, 1934). It behooves plant breeders and gene bank curators therefore to examine the morphological and physiological characteristics in available germplasm and identify superior genotypes to enhance crop adaptation in different climates. Moreover, the use of geographic information systems and passport data can allow identification of accessions from stress-prone environments (Tardieu, 2014). 
Many researchers have used dormant cuttings to determine the chilling requirement of apple, peach, almond, and grapevine (Alonso et al., 2005; Dejampoor and Grigorian, 2000; Dokoozlian, 1999; Jacobs et al., 2002). Also, several models have been developed to measure chilling requirement in fruit trees including the Utah model (Richardson et al., 1974); low-chilling model (Gilreath and Buchanan, 1981); Aron model (Aron, 1983); Dynamic model (Erez et al., 1979), North Carolina model (Shaltout and Unrath, 1983), etc. It has been suggested that some pomegranate cultivars require 100 to $150 \mathrm{~h}$ to fulfil their chilling requirement (Ashton, 2006). However, there are limited reports on chilling and heat requirements in pomegranates, most especially, domesticated pomegranate cultivars in Iran. The objectives of this study were to 1) determine the chilling and heat requirements for breaking of bud dormancy in 20 Iranian pomegranate cultivars; 2) examine the correlations of chilling and heat requirements with tree and fruit characteristics; and 3) evaluate the possible relationship between geographical/climatic parameters of original plant locations and chilling and heat requirement, as well as tree and fruit characteristics.

\section{Materials and Methods}

Plant materials. Twenty pomegranate cultivars and landraces were obtained from the main pomegranate repository in Iran located at the Agriculture and Natural Resources Research Center (ANRRC) in Yazd Province. Two cultivars including Rabab Poost Ghermez Neyriz and Malas Yazdi are widely cultivated, whereas the rest are of local importance in different provinces in Iran, with the exception of 'Torosh Nar Riz Zirab', which is a noncommercial cultivar from the Darab Region (Table 1). All the accessions were collected 26 years ago from many provinces with diverse climates and are kept in main pomegranate repository of Iran located at the ANRRC in Yazd Province.

Geographical and climatic parameters of the sampling locations. The geographic and climatic data $(\approx 10-20$ years, depending on availability) of the locations from which accessions were collected including altitude, minimum and maximum temperatures, mean daily temperature, average wind speed, and average rainfall were obtained from meteorological stations in Iran (Table 2).

Chilling treatment in the laboratory. In Nov. 2014, immediately after leaf abscission and before chilling accumulation; when the

Table 1. Name, origin, fruit, and tree characteristics of the pomegranate cultivars used in this study.

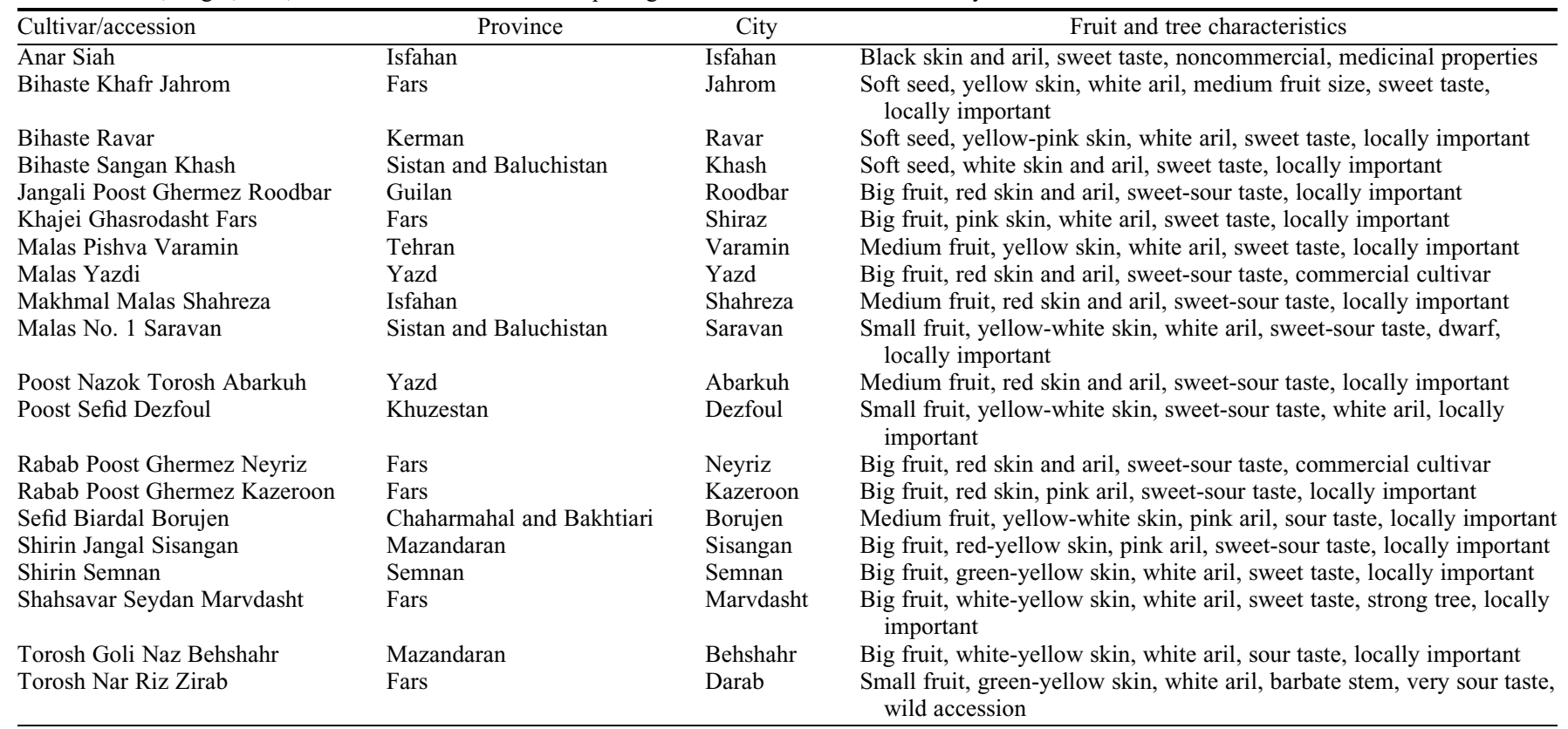

Table 2. Geographic/climatic parameters (including 10-20 years of data, depending on availability) of the original environment of the cultivars/accessions obtained from 20 meteorological stations in Iran.

\begin{tabular}{|c|c|c|c|c|c|c|}
\hline Cultivar/accession & $\begin{array}{l}\text { Minimum } \\
\text { temp }\left(0^{\circ} \mathrm{C}\right)\end{array}$ & $\begin{array}{l}\text { Maximum } \\
\text { temp }\left(0^{\circ} \mathrm{C}\right)\end{array}$ & $\begin{array}{l}\text { Mean daily } \\
\text { temp }\left(0^{\circ} \mathrm{C}\right)\end{array}$ & $\begin{array}{l}\text { Mean wind } \\
\text { speed (knots) }\end{array}$ & $\begin{array}{l}\text { Mean precipitation } \\
(\mathrm{mm})\end{array}$ & Altitude $(\mathrm{m})$ \\
\hline Bihaste Khafr Jahrom & 7.31 & 33.9 & 23.4 & - & 310.0 & $1,100.0$ \\
\hline Bihaste Ravar & 8.6 & 25.7 & 15.9 & 6.1 & 148.0 & $1,753.0$ \\
\hline Jangali Poost Ghermez Roodbar & 9.6 & 19.6 & 16.0 & 2.5 & $1,337.0$ & -8.6 .0 \\
\hline Khajei Ghasrodasht Fars & 9.9 & 25.8 & 17.8 & 4.4 & 334.0 & $1,484.0$ \\
\hline Malas Pishva Varamin & 10.7 & 22.5 & 17.4 & 5.2 & 232.7 & $1,190.0$ \\
\hline Malas No. 1 Saravan & 13.8 & 29.8 & 22.2 & 6.0 & 107.0 & $1,195.0$ \\
\hline Poost Nazok Torosh Abarkuh & 5.5 & 31.3 & 20.2 & 3.5 & 59.11 & $1,550.0$ \\
\hline Poost Sefid Dezfoul & 15.9 & 32.2 & 24.2 & 3.5 & 394.0 & 143.0 \\
\hline Rabab Poost Ghermez Neyriz & 13.4 & 26.4 & 19.4 & 5.3 & 204.9 & $1,632.0$ \\
\hline Rabab Poost Ghermez Kazeroon & 15.5 & 30.1 & 22.9 & 4.2 & 291.0 & 840.0 \\
\hline Sefid Biardal Borujen & 2.7 & 18.2 & 10.4 & 4.5 & 254.0 & $2,260.0$ \\
\hline Shirin Jangal Sisangan & 5.6 & 15.9 & 16.2 & 3.5 & $1,272.0$ & -20.9 .0 \\
\hline
\end{tabular}


temperature was $\approx 15{ }^{\circ} \mathrm{C}, 1$-year-old cuttings were obtained from $\approx 26$-year-old trees of each pomegranate cultivar/accession at the repository in Yazd Province. To avoid dehydration, the bud sticks were put into a plastic box and wrapped in a damp cloth. Cuttings were transported to the laboratory and surface sterilized by immersing in $4000 \mathrm{ppm}$ benomyl (Ariashimi Co., Zahedan, Iran) solution, for $5 \mathrm{~min}$, and placed in sealed plastic bags under cold storage. Twigs were cut into segments of $\approx 20 \mathrm{~cm}$ long to obtain a total of 270 stem cuttings per cultivar ( 9 chilling treatments plus 3 replicates and 10 cuttings per replicate). Only one axillary bud was retained, whereas other buds were eliminated.

For chilling treatment, separate packs of cuttings from each cultivar wrapped in a damp cloth placed in sealed plastic bags were stored at $4 \pm 1{ }^{\circ} \mathrm{C}$ for 0 (control), 100 , 200, 300, 400, 500, 600, 700, and $800 \mathrm{~h}$.

Following chilling treatment, the cuttings were placed in end sealed pots of $0.3 \mathrm{~L}$, filled with distilled water, and forced to grow in the laboratory under continuous white light and varied temperatures of 18 and $26{ }^{\circ} \mathrm{C}$ (for night and day, respectively). The basal ends of the cuttings were recut three times a week, whereas the water in the pot was replaced daily. Budbreak was observed when the phonologic stage was at sprouting of first leaves [i.e., bud dormancy was overcome when $50 \%$ of the buds had reached this stage (Richardson et al., 1974)]. Every 3 d between Dec. 27 and Feb. 2, budbreak data were collected using the same chilling and forcing procedures as previously described.

For each cultivar, heat requirement was calculated as the number of GDHs accumulated from the stage when the cuttings were transferred from refrigerator to the laboratory until $50 \%$ of buds reached the sprouting of first leave. Pomegranate phenological development threshold is taken as $10^{\circ} \mathrm{C}$ (Jackson, 1999; Melgarejo et al., 1997). Based on Richardson et al. (1974), one GDH ${ }^{\circ} \mathrm{C}$ is defined as $1 \mathrm{~h}$ at the temperature $1{ }^{\circ} \mathrm{C}$ above the base temperature. Thus, GDH was calculated from hourly temperature between 10 and $25^{\circ} \mathrm{C}$ and all temperatures above $25^{\circ} \mathrm{C}$ were considered equal to $25^{\circ} \mathrm{C}$.

Measurement of seed physical properties. For each cultivar, fruits were harvested at commercial maturity in 2014 (before cuttings for chilling treatment were collected). The hardness of fresh seed (immediately after removal from aril flesh) was measured using 20 individual seeds per fruit and 6 fruits per cultivar/accession. Measurements were carried out using an Instron texture analyzer (STM-20; SANTAM, Iran) with 75-mm compression platen probe. The operating conditions of the machine were a test speed of $0.5 \mathrm{~mm} \cdot \mathrm{s}^{-1}$ and a trigger force of $0.20 \mathrm{~N}$. Hardness $(\mathrm{N})$ of the seed was taken as the force in compression corresponding to the shattering of the seed (Al-Said et al., 2009; Kingsly et al., 2006).

Stomatal density. Fully expanded leaves were randomly collected from the midpoint of the current season's shoots. Stomata numbers were determined using the replica method (Soleimani et al., 2002). The stellate hairs were removed from the lower surface of each leaf, using an adhesive tape. A thin film of cellulose acetate was painted directly onto the lower epidermis of the leaf and allowed to dry at room temperature before removal. Sections were taken from the middle of each leaf and placed on coded slides. A binocular microscope was used for stomatal counts at $\times 40$ magnification. Stomatal density was determined in a field area of $1 \mathrm{~mm}^{2}$.

Experimental design and statistical analysis. The experiment design was in the form of completely randomized design with three replications. Data analysis was based on the analysis of variance procedure with means tested for significant differences at $P<0.05$ using Duncan's multiple range test in SAS, version 9.1 (Institute, 2003). Correlations between pairs of traits were estimated based on Pearson's correlation coefficient (PROC CORR) in SAS. The results were expressed as means \pm SE.

\section{Results}

Chilling and heat requirements. The pomegranate cultivars and accessions showed a wide range of chilling (233-633 h) and heat requirements (4096-7928 GDH) for budbreak (Table 3 ). The cultivars could be classified into two groups based on chilling requirement as follows: 1) very low chill cultivars (233-400 h) including Bihaste Ravar, Anar Siah, and Bihaste Sangan Khash, Sefid Biardal Borujen, Khajei Ghasrodasht, and Shirin Jangal Sisangan; and 2) low chill cultivars (400-633 h) including Bihaste Khafr Jahrom, Torosh Goli Naz Behshahr,

Table 3. Chilling and heat $(\mathrm{GDH})$ requirements of the 20 pomegranate cultivars.

\begin{tabular}{lcc}
\hline Cultivar/accession & Chilling requirement $(\mathrm{h})$ & Heat requirement GDH $\left({ }^{\circ} \mathrm{C}\right)$ \\
\hline Bihaste Ravar & $233.33 \pm 27.21 \mathrm{f}$ & $5,328 \pm 346 \mathrm{bcde}^{\mathrm{z}}$ \\
Anar Siah & $266.66 \pm 27.21 \mathrm{ef}$ & $4,836 \pm 127 \mathrm{bcde}$ \\
Bihaste Sangan Khash & $266.66 \pm 27.21 \mathrm{ef}$ & $4,188 \pm 137 \mathrm{de}$ \\
Shirin Jangal Sisangan & $366.66 \pm 27.21 \mathrm{de}$ & $4,652 \pm 552 \mathrm{cde}$ \\
Sefid Biardal Borujen & $366.67 \pm 27.21 \mathrm{de}$ & $4,976 \pm 305 \mathrm{bcde}$ \\
Khajei Ghasrodasht Fars & $366.66 \pm 27.21 \mathrm{de}$ & $5,192 \pm 356 \mathrm{bcde}$ \\
Bihaste Khafr Jahrom & $400.00 \pm 0 \mathrm{~cd}$ & $4,752 \pm 352 \mathrm{bcde}$ \\
Torosh Goli Naz Behshahr & $400.00 \pm 0 \mathrm{~cd}$ & $5,616 \pm 0 \mathrm{bcd}$ \\
Malas No 1 Saravan & $433.33 \pm 27.21 \mathrm{~cd}$ & $4,096 \pm 313 \mathrm{e}$ \\
Poost Sefid Dezfoul & $450.00 \pm 23.5 \mathrm{~cd}$ & $5,824 \pm 762 \mathrm{bc}$ \\
Shahsavar Seydan Marvdasht & $466.66 \pm 54.4 \mathrm{bcd}$ & $4,304 \pm 13 \mathrm{de}$ \\
Torosh Nar Riz Zirab & $466.66 \pm 54.43 \mathrm{bcd}$ & $4,628 \pm 309 \mathrm{cde}$ \\
Rabab Poost Ghermez Kazeroon & $533.33 \pm 54.43 \mathrm{abc}$ & $6,016 \pm 163 \mathrm{bc}$ \\
Shirin Semnan & $533.33 \pm 54.4 \mathrm{abc}$ & $4,288 \pm 13 \mathrm{de}$ \\
Malas Pishva Varamin & $533.33 \pm 54.4 \mathrm{abc}$ & $6,124 \pm 464 \mathrm{~b}$ \\
Jangali Poost Ghermez Roodbar & $600.00 \pm 0 \mathrm{ab}$ & $5,244 \pm 458 \mathrm{bcde}$ \\
Makhmal Malas Shahreza & $600.00 \pm 0 \mathrm{ab}$ & $4,920 \pm 264 \mathrm{bcde}$ \\
Rabab Poost Ghermez Neyriz & $600.00 \pm 0 \mathrm{ab}$ & $4,920 \pm 264 \mathrm{bcde}$ \\
Poost Nazok Torosh Abarkuh & $633.33 \pm 27.21 \mathrm{a}$ & $5,336 \pm 464 \mathrm{bcde}$ \\
Malas Yazdi & $633.33 \pm 27.21 \mathrm{a}$ & $7,928 \pm 251 \mathrm{cde}$ \\
\hline GDH growing degree hour. & &
\end{tabular}

GDH, growing degree hour.

${ }^{\mathrm{z}}$ Similar letters in each column indicate nonsignificant differences among cultivars at $P \leq 0.05$ based on Duncan's multiple range test.

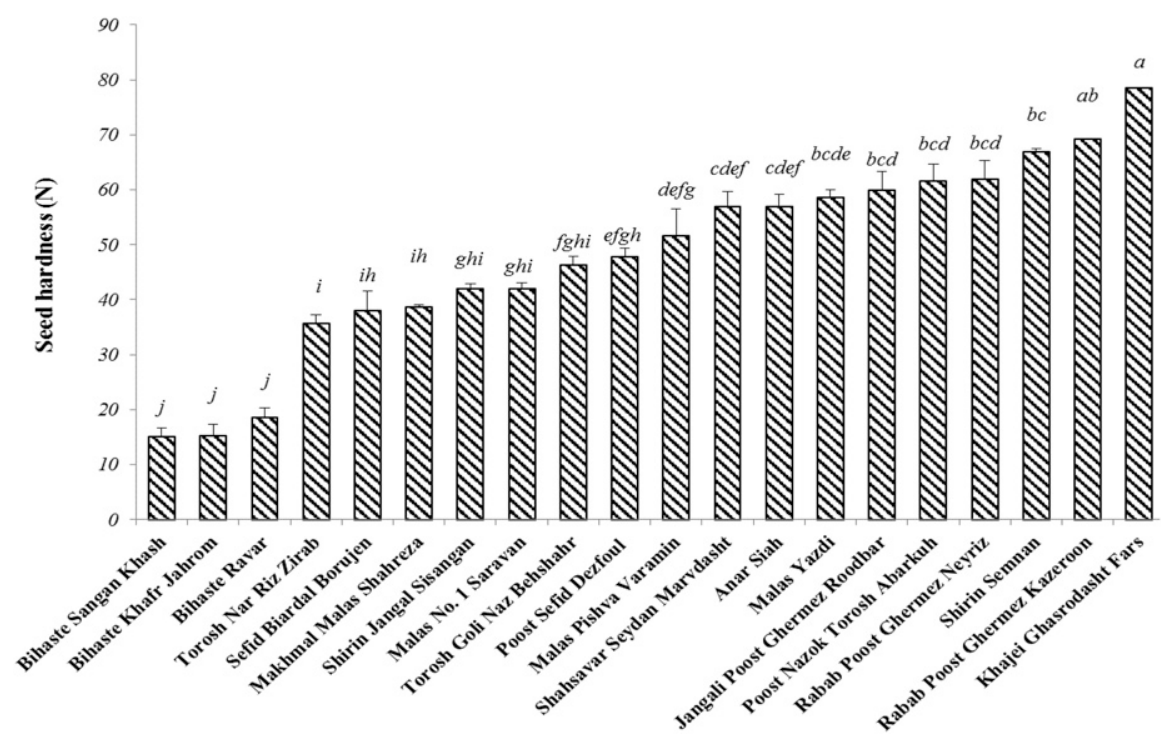

Fig. 1. Frequency distribution of seed hardness in 20 pomegranate cultivars. Similar letters indicate nonsignificant differences among cultivars $(P \leq 0.05)$. 
Malas No. 1 Saravan, Poost Sefid Dezfoul, Shahsavar Seydan Marvdasht, Torosh Nar Riz Zirab, Malas Pishva Varamin, Shirin Semnan, Rabab Poost Ghermez Kazeroon, Jangali Poost Ghermez Roodbar, Rabab Poost Ghermez Neyriz, Makhmal Malas Shahreza, Poost Nazok Torosh Abarkuh, and Malas Yazdi (Table 3).

The cultivars were also classified into two groups based on heat requirement as follows: 1 ) low heat requiring cultivars (4096-6000 GDH) including Malas No. 1 Saravan, Shirin Semnan, Bihaste Sangan Khash, Shahsavar Seydan Marvdasht, Torosh Nar Riz Zirab, Shirin Jangal Sisangan, Bihaste Khafr Jahrom, Anar Siah, Rabab Poost Ghermez Neyriz, Makhmal Malas Shahreza, Sefid Biardal Borujen, Khajei Ghasrodasht Fars, Jangali Poost Ghermez Roodbar, Bihaste Ravar, Poost Nazok Torosh Abarkuh, and Poost Sefid Dezfoul; and 2) high heat requiring cultivars (6000-7928 GDH) including Torosh Goli Naz Behshahr, Rabab

Table 4. Pearson's correlation coefficients between pairs of traits based on 20 pomegranate cultivars.

\begin{tabular}{lcr}
\hline Variable & Chilling requirement & GDH \\
\hline Seed hardness & 0.44 & 0.07 \\
& $P=0.0004$ & $P=0.89$ \\
Stomatal density & $P=0.42$ & -0.15 \\
\hline
\end{tabular}

GDH, growing degree hour.
Poost Ghermez Kazeroon, Malas Pishva Varamin, and Malas Yazdi (Table 3).

Seed hardness. A range of variation in seed hardness $(15-78 \mathrm{~N})$ was observed among cultivars (Fig. 1). The maximum seed hardness $(78 \mathrm{~N})$ was observed in 'Khajei Ghasrodasht Fars', whereas the lowest seed hardness was observed mainly in soft seeded cultivars including Bihaste Sangan Khash $(15 \mathrm{~N})$, Bihaste Khafr Jahrom (15 N), and Bihaste Ravar (18 N).

Seed hardness and chilling requirement were positively correlated albeit medium $(r=0.44)$, whereas a low but nonsignificant correlation was observed between heat requirement (GDH) and seed hardness $(r=0.07)$ (Table 4).

Stomatal density. A large variation of stomata density ranging from 46 stomata/ $\mathrm{mm}^{2}$ (in 'Shahsavar Seydan Marvdasht') to 108 stomata $/ \mathrm{mm}^{2}$ (in 'Shirin Semnan') was observed in the pomegranate cultivars (Fig. 2). There was a positive correlation $(r=0.42)$ between chilling requirement and stomatal density, whereas no correlation $(r=-0.15)$ was observed between heat requirement and stomatal density (Table 4).

Relationships of chilling and heat requirements, geographical and climatic parameters, and tree and fruit characteristics. Among climatic parameters, only wind speed showed a negative medium but significant correlation with chilling requirement

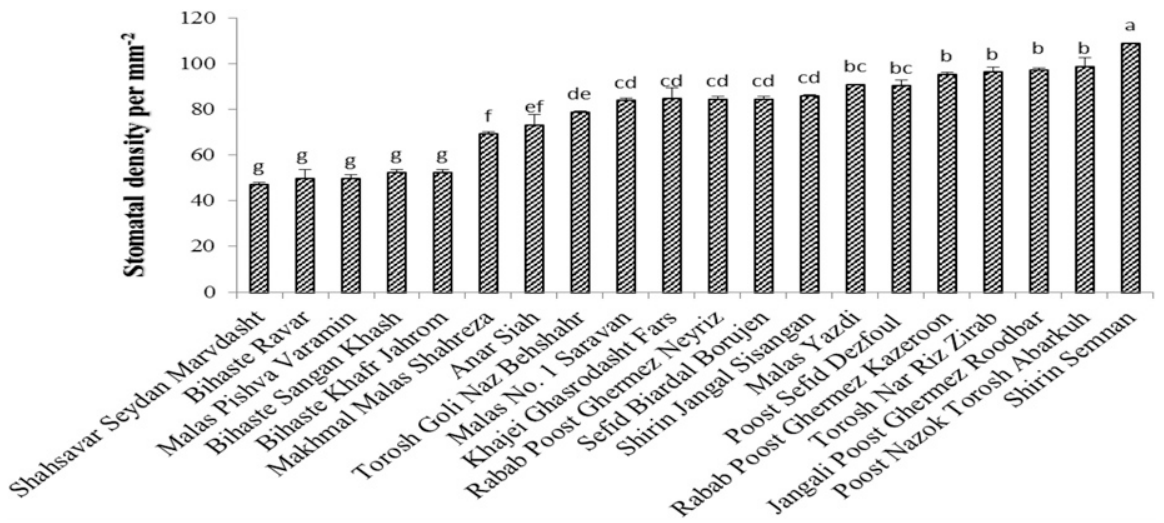

Fig. 2. Frequency distribution of stomatal density in 20 pomegranate cultivars. Similar letters indicate nonsignificant differences among cultivars $(P \leq 0.05)$.

$(r=-0.39 ; P=0.002)$ (Fig. 3A). Also, stomatal density recorded a relatively high correlation with wind speed $(r=-0.57 ; P=0.0001)$ (Fig. 3C) and altitude $(r=-0.34 ; P=0.006)$ (Fig. 3B).

\section{Discussion}

Information on chilling requirement in pomegranate is scarce. In this study, we observed significant differences in chilling requirement of the pomegranate cultivars studied, showing a range from 233 to $633 \mathrm{~h}$. Samish and Lavee (1982) observed that chilling requirement in plant species and cultivars was genetically determined. Ashton (2006) noted that most pomegranate trees do not need winter chilling, since pomegranates are mainly grown in semitropical areas that do not have temperatures below freezing in winter. On the other hand, Glozer and Ferguson (2008) suggested that the chilling requirement of pomegranate cultivars such as Sweet Pomegranate, Red Silk, Grenada, Ever sweet, and Wonderful ranged between 100 and $150 \mathrm{~h}$ below $6^{\circ} \mathrm{C}$. The much higher chilling requirement ( 600 to $633 \mathrm{~h}$ ) that we observed in our study highlights the risk of growing these cultivars in warm climates lacking sufficient chilling temperatures for budbreak. Erez (2000) and Aslamarz et al. (2009) also reported the risk of yield losses if high chill cultivars are grown in warm regions. Thus, 'Poost Nazok Torosh Abarkuh', 'Malas Yazdi', 'Rabab Poost Ghermez Neyriz', and 'Makhmal Malas Shahreza' would appear to be more suitable for cultivation in cooler climates or on high altitudes in areas with warm climate to avoid issues related to lack of sufficient chill. Interestingly, soft seeded pomegranate cultivars such as Bihaste Ravar and Bihaste Sangan Khash showed the lowest chilling requirements in our study.

There was a moderate correlation between the geographical/climatic parameters of natural habitat of cultivars and their chilling requirement. For example, interestingly, cultivars grown in the regions with the highest wind speed such as 'Bihaste Ravar' (in Ravar, Kerman Province), 'Bihaste Sangan Khash' (in Khash, Sistan and Baluchistan Province), and 'Anar Siah' (in Isfahan,
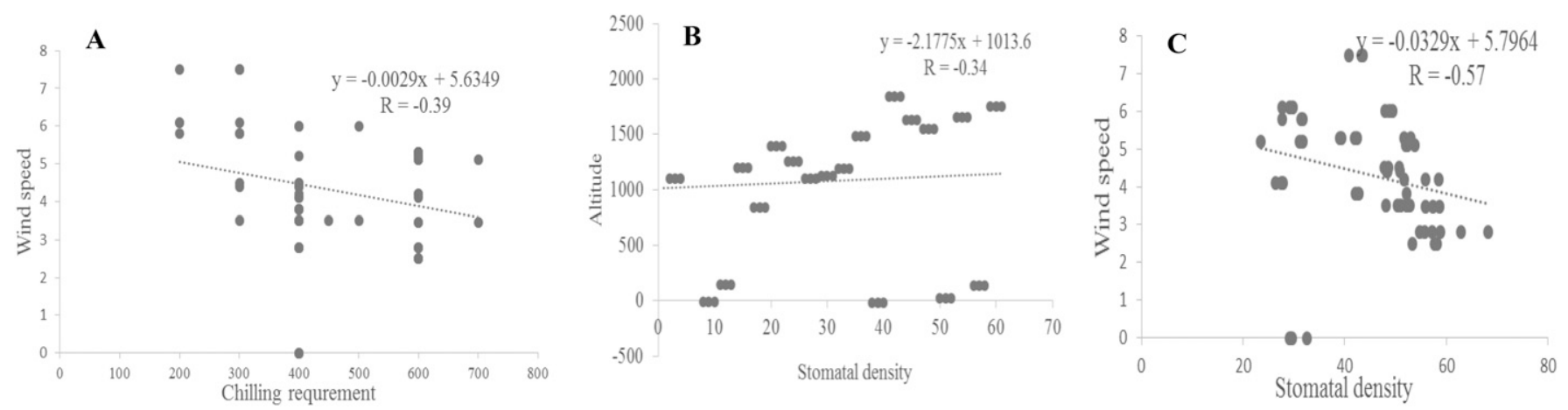

Fig. 3. Pearson's correlation coefficients between pairs of traits including (A) chilling requirement and wind speed, (B) stomatal density and altitude, and (C) stomatal density and wind speed. 
Isfahan Province) ranked as cultivars with the lowest chilling requirements. On the other hand, cultivars with high chilling requirement such as 'Poost Nazok Torosh Abarkuh' and 'Shirin Semnan' are leading cultivars of Semnan and Yazd provinces, respectively. These are regions with a relatively mild wind speed (2.8 and 3.5 knots, respectively). We suggest that this information could be used to identify the most suitable cultivars for cultivation in a particular area, as well as the most appropriate areas for pomegranate production.

Ikinci et al. (2014) reported that in pomegranate similar to other tree fruit species, such as almond, pistachio, apricot, and sweet cherry, heat requirement regulate flowering, and is very important for fruit cultivation. Moreover, Spiegel-Roy (1979) suggested that high heat requirement is partly attributed to a residual effect of dormancy. Our data showed variation in heat requirement from 4096 to $7928^{\circ} \mathrm{C}$, which contrasts Ikinci et al. (2014) results which showed a narrow range in heat requirement $\left(7373\right.$ to $\left.8008{ }^{\circ} \mathrm{C}\right)$ for a group of Turkish pomegranate cultivars including Suruc, Katirbasi, and Hicaznar. 'Malas Yazdi', in particular showed as very high heat requirement (7928 GDH). It appears that the heat requirement of pomegranate cultivars is affected by climate, altitude, cultivar, age of the tree, models used for estimation, and the year that experiment is carried out (Ikinci et al., 2014). Our results showed that chilling requirement was independent of altitude $(r=-0.15)$, while interestingly, a negative correlation was observed between chilling requirement and wind speed ( $r=-0.39$ ) (Fig. 3A).

Stomata density ranged from 46 stomata/ $\mathrm{mm}^{2}$ (in 'Shahsavar Seydan Marvdasht') to 108 stomata $/ \mathrm{mm}^{2}$ (in 'Shirin Semnan') in our study. This result is lower than those reported by Drogoudi et al. (2012) in four pomegranate cultivars which ranged between 68 and 149.9 stomata $/ \mathrm{mm}^{2}$ and Meena et al. (2011), who reported a maximum density of 130.67 per $\mathrm{mm}^{2}$. The discrepancy between our results and those of other authors could be due to cultivar or climate differences among studies. In this study, we observed a significant and positive correlation $(r=0.42)$ between chilling requirement and stomatal density (Table 4). We also observed that low chill cultivars such as Bihaste Ravar, Bihaste Khafr Jahrom, and Bihaste Sangan Khash had low stomatal density (between 49 to 52 stomata $/ \mathrm{mm}^{2}$ ). High chill cultivars including Poost Nazok Torosh Abarkuh, Malas Yazdi, and Jangali Poost Ghermez Roodbar, on the other hand, had relatively high stomatal density of 98,97 , and 90 stomata $/ \mathrm{mm}^{2}$, respectively. However, stomatal density did not show any correlation with heat requirement (Table 4). Stomata are the pores on the surface of leaves, flanked by guard cells, which regulate the gas exchange between internal tissues and its environment (Zhang et al., 2012). Stomata are very important since they are directly responsible for the trade-off between water loss and carbon acquisition (Raven, 2002). Some plant species have been reported as having a generally high heritability (i.e., less dependence on environmental change) for stomatal traits (Orlovic et al., 1998; Sharma and Dunn, 1969). Thus, stomatal density as a quantitative attribute is genetically determined (Gailing et al., 2008). Roselli et al. (1989) suggested that stomatal density is a useful index for scoring for frost tolerance in olives. There are no reports on the correlations between chilling requirement and stomatal density in other plant species.

Our results demonstrate that stomatal density is significantly medium correlated with geographic and geographic/climatic parameters such as altitude and wind speed (Fig. 3B and C). Traditionally, correlations of particular morphological characteristics of vegetation assemblages of single species to habitat qualities are referred to as adaptations (Bock and Von Wahlert, 1965; Koehl, 1996), that is, they promote the fitness of species in their particular habitat. Many studies rely on statistical correlations and assign patterns of morphological traits to the most probable environmental drivers (Kluge and Kessler, 2007). A number of the morphological patterns observed in our study have been previously documented among seed plants and subjected to tests of their functionality (Kluge and Kessler, 2007).

We observed significant differences $(P \leq$ $0.01)$ in seed hardness $(\mathrm{N})$ among cultivars ranging between 15 and $78 \mathrm{~N}$ (Fig. 2). Not surprisingly, 'Bihaste Sangan Khash', 'Bihaste Khafr Jahrom', and 'Bihaste Ravar' that are soft seeded, showed the lowest seed hardness $(15-18 \mathrm{~N})$. These results are in line with those reported by Al-Said et al. (2009) who classified Oman pomegranate cultivars into two groups of soft seed cultivars such as Jabal 1 and Jabal (24-27 N) and hard seed cultivars including Jabal 3 and the wild cultivar (39-44 N). Kingsly et al. (2006) also reported a range of 49.61 to $86.72 \mathrm{~N}$ for seed hardness of pomegranate in different moisture content. Soft seeded cultivars such as Bihaste Sangan Khash and Bihaste Ravar are the leading cultivars in Khash (belonging to Sistan and Baluchistan Province) and Ravar in Kerman Province, respectively, which have mild winters. There was no correlation between seed hardness and heat requirement.

\section{Conclusions}

The chilling and heat requirements of the 20 pomegranate cultivars ranged from 233 to $633 \mathrm{~h}$ and 4096 to $7928 \mathrm{GDH}$, respectively. Soft seeded cultivars such as Bihaste Sangan Khash, Bihaste Ravar, and Anar Siah were categorized as very low chill cultivars (233 h), whereas Poost Nazok Torosh Abarkuh, Malas Yazdi, and Rabab Poost Ghermez Neyriz were grouped as low chill cultivars $(633 \mathrm{~h})$. Cultivars with higher chilling requirement would have a low probability of successful cultivation in areas with very warm winters than soft seeded cultivars that are low chill. Suitable correlation was observed between chilling requirement and geographical/climatic parameters including wind speed and altitude, as well as with tree and fruit characteristics such as stomatal density and seed hardness. We suggest that chilling and heat requirement are two important factors for consideration in the selection of pomegranate cultivars for adjacent areas or in different regions worldwide. For this purpose, tree and fruit characteristics, as well as geographic/climatic parameters of the original tree locations could be used as indirect indicators.

\section{Literature Cited}

Al-Said, F., L.A. Opara, and R. Al-Yahyai. 2009. Physico-chemical and textural quality attributes of pomegranate cultivars (Punica granatum L.) grown in the Sultanate of Oman. J. Food Eng. 90:129-134.

Allan, P. and M.J. Burnett. 1995. Peach production in an area with low winter chilling. J. South. Afr. Soc. Hort. Sci. 5:15-18.

Alonso, J., J. Ansón, and M. Espiau. 2005. Determination of endodormancy break in almond flower buds by a correlation model using the average temperature of different day intervals and its application to the estimation of chill and heat requirements and blooming date. J. Amer. Soc. Hort. Sci. 130:308-318.

Aron, R. 1983. Availability of chilling temperatures in California. Agr. Meteorol. 28:351-363.

Ashton, R.B. 2006. Incredible pomegranate: Plant and fruit. Third Millennium Publishing, Tempe, AZ.

Aslamarz, A.A., K. Vahdati, M. Rahemi, and D. Hassani. 2009. Estimation of chilling and heat requirements of some Persian walnut cultivars and genotypes. HortScience 44:697-701.

Atkinson, C., R. Brennan, and H. Jones. 2013. Declining chilling and its impact on temperate perennial crops. Environ. Expt. Bot. 91:48-62.

Babu, D.K. 2010. Floral biology of pomegranate (Punica granatum L.). Pomegranate. Fruit Veg. Cereal Sci. Biotechnol. 4:45-50.

Bock, W.J. and G. Von Wahlert. 1965. Adaptation and the form-function complex. Evolution 19:269-299.

Dejampoor, J. and V. Grigorian. 2000. Assessing the dormancy characteristics of some commercial almond cultivars for different climates. Iran Agr. Res. 19:181-192.

Dokoozlian, N. 1999. Chilling temperature and duration interact on the budbreak of Perlette' grapevine cuttings. HortScience 34:1-3.

Drogoudi, P., G. Pantelidis, and A. Manganaris. 2012. Morphological and physiological characteristics in pomegranate cultivars with different yields. Options Méditerranéennes. 103:67-69.

Dupré, C. and J. Ehrlén. 2002. Habitat configuration, species traits and plant distributions. J. Ecol. 90:796-805.

Erez, A. 2000. Bud dormancy; phenomenon, problems and solutions in the tropics and subtropics, p. 17-48. Temperate fruit crops in warm climates. Springer, the Netherlands.

Erez, A., G.A. Couvillon, and C.H. Hendershott. 1979. The effect of cycle length on chilling negation by high temperatures in dormant peach leaf buds. J. Amer. Soc. Hort. Sci. 104:573-576.

Faust, M., D. Liu, M.M. Millard, and G. Stutte. 1991. Bound versus free water in dormant apple buds a theory for endodormancy. HortScience 26:887-890

Gailing, O., R. Langenfeld?Heyser, A. Polle, and R. Finkeldey. 2008. Quantitative trait loci 
affecting stomatal density and growth in a Quercus robur progeny: Implications for the adaptation to changing environments. Glob. Change Biol. 14:1934-1946.

Gilreath, P.R. and D.W. Buchanan. 1981. Rest prediction model for low-chilling 'Sungold' nectarine. J. Amer. Soc. Hort. Sci. 106:426-429.

Glozer, K. and L. Ferguson. 2008. Pomegranate production in Afghanistan. UCDAVIS College of Agricultural \& Environmental Sciences.

Gratacós, E. and A. Cortés. 2007. Chilling requirements of cherry cultivars. Compact Fruit Tree. 40:7-9.

Holland, D., K. Hatib, and I. Bar-Ya'akov. 2009. Pomegranate: Botany, horticulture, breeding. Hort. Rev. 35:127-191.

Ikinci, A., M. Mamay, L. Unlu, I. Bolat, and S. Ercisli. 2014. Determination of heat requirements and effective heat summations of some pomegranate cultivars grown in Southern Anatolia. Erwerbs-Obstbau 56:131-138.

Institute, S. 2003. SAS version 9.1. SAS Institute, Cary, NC.

Jackson, D. 1999. Climate and fruit plants, p. 321. In: D. Jackson and E.L. Norman (eds.). Temperate and subtropical fruit production. 2nd ed. CABI Publications, Cambridge.

Jacobs, J.N., G. Jacobs, and N.C. Cook. 2002. Chilling period influences the progression of bud dormancy more than does chilling temperature in apple and pear shoots. J. Hort. Sci. Biotechnol. 77:333-339.

Kingsly, A., D. Singh, M. Manikantan, and R. Jain. 2006. Moisture dependent physical properties of dried pomegranate seeds (Anardana). J. Food Eng. 75:492-496.

Kluge, J. and M. Kessler. 2007. Morphological characteristics of fern assemblages along an elevational gradient: Patterns and causes. Ecotropica (Bonn) 13:27-43.

Koehl, M. 1996. When does morphology matter? Annu. Rev. Ecol. Syst. 27:501-542.

Lang, G.A. 1987. Dormancy: A new universal terminology. HortScience 22:817-820.

Meena, K., R. Singh, S. Pareek, P. Kashyap, M. Sheikh, A. Mokashi, and A. Rokhade. 2011. Evaluation of pomegranate (Punica granatum L.) genotypes for morphological and flowering characteristics under semi-arid climate. Acta Hort. 890:233-238.

Melgarejo, P., R. Martinez-Valero, J.M. Guillamon, M. Miro, and A. Amoros. 1997. Phenological stages of the pomegranate tree (Punica granatum L.). Ann. Appl. Biol. 130:135-140.

Orlovic, S., V. Guzina, B. Krstic, and L. Merkulov. 1998. Genetic variability in anatomical, physiological and growth characteristics of hybrid poplar (Populus $\times$ euramericana Dode (Guinier)) and eastern cottonwood (Populus deltoides Bartr.) clones. Silvae Genet. 47:183-189.

Porter, J. and H.Y. Wetzstein. 2014. The biology of pomegranates: All about flowers, fruit and arils. Florida Pomegranate Association University of Georgia/Purdue University.

Raven, J.A. 2002. Selection pressures on stomatal evolution. New Phytol. 153:371-386.

Raven, P.H. and G.B. Johnson. 1986. Biology. Times Mirror/Mosby College Publishing, St. Louis, MO.

Richardson, E.A., S.D. Seeley, and D.R. Walker. 1974. A model for estimating the completion of rest for "Redhaven" and "Elberta" peach trees. HortScience 1:331-332.

Roselli, G., G. Benelli, and D. Morelli. 1989. Relationship between stomatal density and winter hardiness in olive (Olea europaea L.). J. Hort. Sci. 64:199-203.

Samish, R.M. and S. Lavee. 1982. The chilling requirement of fruit trees, p. 372-388. Proc. XVI International Horticultural Congress.

Shaltout, A. and C. Unrath. 1983. Effect of some growth regulators and nutritional compounds as substitutes for chilling of Delicious apple leaf and flower buds. J. Amer. Soc. Hort. Sci. 108:898-901.

Sharma, G.K. and D.B. Dunn. 1969. Environmental modifications of leaf surface traits in Datura stramonium. Can. J. Bot. 47:1211-1216.

Soleimani, A., H. Lessani, and A. Talaie. 2002. Relationship between stomatal density and ionic leakage as indicators of cold hardiness in olive (Olea europaea L.). XXVI International Horticultural Congress: Environmental Stress and Horticulture Crops. 618:521-525.

Spiegel-Roy, P.F.H.A. 1979. Chilling and postdormant heat requirement as selection criteria for late-flowering pears. J. Hort. Sci. 54:115120 .

Tardieu, F. 2014. Plant response to environmental conditions: Assessing potential production, water demand, and negative effects of water deficit. Drought phenotyping in crops. Frot. physiol. 4:1-11.

Weldon, G.P. 1934. Fifteen years study of delayed foliation of deciduous fruit trees in southern California. Calif. Agr. Bull. 23:160181 .

Zhang, L., H. Niu, S. Wang, X. Zhu, C. Luo, Y. Li, and X. Zhao. 2012. Gene or environment? Species-specific control of stomatal density and length. Ecol. Evol. 2(5):1065-1070. 